\title{
Financial Globalisation and Crisis Occurrence: Does Threshold Effect of Financial Development Matter?
}

\author{
Noureddine Khadraoui* \\ Department of Economics, Faculty of Economic Sciences and Management, University of Sousse, Tunisia. \\ *Corresponding Author: E-mail: kadnour@yahoo.fr
}

\begin{abstract}
This paper studies the relationship between financial globalisation and occurrence of crises according to the level of financial development condition. We demonstrate that economies with high level of financial sector development benefit more from financial integration than those with a lower one. More specifically, we will investigate the issues relevant to threshold effect of financial development on which capital flows changes effects sign on probability of crisis occurrence. We investigate the role of financial development in the relationship between capital flows and crisis occurrence probability for different groups of countries. Estimations are conducted with a panel data of 70 countries over the period 1984-2009 using fixed effects logit panel estimation. Empirical results support that capital movements can create bubble economy according to the level of domestic financial development. This implies that countries which are at an intermediate phase of financial development are the most vulnerable to crisis.
\end{abstract}

Keywords: Financial development, Financial globalization, Financial crisis.

\section{Introduction}

After financial crises of the 1980s and 1990 which followed reforms of liberalization of the capital account, some studies supported that capital flows could be a source of bigger macroeconomic volatility. This is going to expose the countries to be vulnerable in the sudden reversals of capital flows, [1]. According to this line of explanation, some countries are going to run a higher macroeconomic volatility by what they miss in terms of political instruments to smooth the cycles. Particularly, they miss adequate financial institutions to avoid sudden reversals of capital flows. Liberalization can lead to financial crises when it is not well managed. If the right financial infrastructure is not in place or is not put in place while integrating, liberalization followed by capital inflows can debilitate the health of the local financial system. The need for strong fundamentals is key since financial globalization tends to intensify a country's sensitivities to foreign shocks. Moreover, international market imperfections can lead to crises and contagion, even in countries with good economic fundamentals.

First, even though domestic factors tend to be key determinants of crises, there are different channels through which financial globalization can be related to crises. First, when a country liberalizes its financial system it becomes subject to market discipline exercised by both foreign and domestic investors. In open economies, the joint Noureddine Khadraoui | Sep.-Oct. 2012 | Vol.1 | Issue 5|45-51 force of domestic and foreign investors might prompt countries to achieve sound fundamentals. Second, globalization can also lead to crises if there are imperfections in international financial markets. This is largely illustrated in the literature following Obstfeld [2]. Imperfections can as well deteriorate fundamentals. For example, moral hazard can lead to over borrowing syndromes when economies are liberalized and there are implicit government guarantees, increasing the likelihood of crises, as argued in [3]. Third, globalization can lead to crises due to the importance of external factors, even in countries with sound fundamentals and even in the absence of imperfections in international capital markets. [4] argue that external factors are important determinants of capital flows to developing countries.

Detailed account of financial crises through history. The particular relation between globalization and crises has inspired many studies like [6]. These authors compare today's wave of globalization with that of a hundred years ago. They conclude that given the level of integration prevalent in the global economy today, it is surprising that financial instability is not worse. Bordo, Eichengreen, and Irwin claim that this pattern can be attributed to the development of institutional innovations both at a global level, like the International Monetary 


\section{Available online at www.managementjournal.info}

Fund (IMF) or the Bank of International Settlements (BIS), and at a local level, such as better accounting standards and contract enforcement. [7] study the frequency, duration, and output impact of crises during the last 120 years. They compare the crises of the 1980s and 1990s with three distinct historical periods: the gold standard era (1880-1913), the inter-war years (1919-1939), and the Bretton Woods period (1945-1971). They conclude that crises are more frequent today than during the Bretton Woods and the gold standard periods.

Today's frequency of crisis is comparable to the inter-war years. There is little evidence that crises have grown longer or output losses have become larger. Bordo, Eichengreen, Klingebiel, and Martinez Peria conclude that, even if more frequent, crises have not become more severe.

Though globalization can lead to crises, a vast literature on financial crises stresses the The crises can be considered as extreme cases of macroeconomic instability. In fact, the succession of financial crises is often perceived as one of the characteristic aspects of the financial globalization intensification during the last decades. Furthermore, the fact that the recent crises mainly affected countries the most committed to financial integration policy makes that these phenomena are considered as characteristics of the uneven distribution of the advantages and risks of globalization. These last ones can carry some risks. These risks are likely to appear particularly in the short run, when countries open up. Liberalization can lead to financial crises when it is not well managed. This imposes us the task to determine if the financial development and the capital flows can be factors which increase the vulnerability in crises.

\section{Empirical Methodology}

The starting point of our analysis is an econometric model of the probability of a systematic banking crisis. This model was adopted by Demirgüç-Kunt and Detragiache, [9]. These last ones estimated diverse specifications of a multivariate logit regression for a big sample of developing countries where some countries have experienced banking crises. In our study, we proceed to explain the occurrence of a financial crisis by some factors which are inspired from crisis literature among which we add our variables of interest which are financial integration and financial development indicators and their interaction. Accordingly, the dependent variable in this model (crisis dummy) takes the value 1 if there is a crisis during the period (19842009) and 0 otherwise. The probability of the importance of domestic factors as key determinant of crises. [8] argue that domestic factors such as slow growth and a boom in domestic credit increase a country's likelihood of experiencing a financial crisis. Kaminsky and Reinhart (1999) argue that crises occur mostly due to domestic factors, as the economy enters a recession following a period of prolonged boom in economic activity fueled by expanded credit, capital inflows, and an overvalued currency. [10] stress the importance of both macroeconomic and microeconomic factors in determining banking crises [11] argue that not only typical macroeconomic indicators such as actual deficits but also other factors like large prospective deficits (associated with implicit bailout guarantees to failing banks) can determine crises. They claim that this was the case of the Asian crisis, where governments were actually running small deficits or surpluses.

occurrence crisis at a particular time in a particular country is explained by a function of a vector of $n$ explanatory variables $X(i, t)$. We denote by $\mathrm{P}(\mathrm{i}, \mathrm{t})$ a dummy variable that takes the value of 1 for crisis occurrence in country $i$ and

Time $\mathrm{t}$ and 0 otherwise. $\square$ is a vector of $\mathrm{n}$ unknown coefficients and $\mathrm{F}\left(\square^{\prime} \mathrm{X}(\mathrm{i}, \mathrm{t})\right)$ denote the function of cumulative probability distribution, for more details see Demirgüç-Kunt and Detragiache, (1998a and 1998b). This logistic distribution was commonly used by [12] and [13]. The timing of crises used in our study is identified and dated from Luc Laeven's and Fabian Valencia's database [14]. As described below, explanatory variables used are the inflation, government spending, GDP growth rate and exchange rate.

At first, we introduce five indicators of financial development used in this research area. For instance, these variables are the ratio of credit to the private sector (credit/GDP), liquid liability ratio (M3 / GDP), the market capitalization, the ratio of the total assets of the financial system and the capacity of transformation of credit by financial intermediaries (the ratio credit / deposit), (for more details of this indicators see [15].

Secondly, we use another regressor that may be a crisis determinant as mentioned in theoretical studies is the financial globalisation proxy. To measure this last one we use the net private capital flows to GDP ratio, (for more details see Mellissi Ferretti study [16]. 
Finally, with the liberalisation of capital markets, the increasing number of financial crises in both developed and developing countries is considered involving large associated costs to official institutions, private entities, and market operators. To do with these institutional factors, we evaluates institutional risks effects on occurrence crisis by using the rating system of International Country Risk Guide, which provide detailed and consistent annual data over an extended period of time for a large number of countries. To include all the political, financial and economic risks, we calculate the country risk by the method of the rating of the ICRG. Thus, the time series data and techniques adopted by ICRG permit us to calculate this composite risk rating from economic, financial and political risk ratings components, (for more details see ICRG).

Moreover, our study provides an international comparison of country groups for 50 developing countries and 20 developed countries from a logit panel data analysis. When using panel data, country fixed effects are included to deal with the change of the dependent variable cross-country independently of explanatory variables, ([17]).

We remind that our hypothesis in this study is to test the contribution of financial development and financial liberalization indicators in the explanation of the financial crises occurrences. Therefore, by using a logit model we make separately regressions on every sample as adopted throughout this work: on one hand, we decline the explained variable $\mathrm{Y}(\mathrm{i}, \mathrm{t})$ on all the macroeconomic and financial variables, and on the other hand, we introduce the interaction between the indicators of the financial development and the liberalization. Specifically, the dependent variable $\mathrm{Y}$ is defined as follows.

\section{$\{Y=1$, occurrence \\ $\{Y=0$, otherwise}

Generally, the model will be noted below. We let $\mathrm{Y}(\mathrm{i}, \mathrm{t})$ be the dependent variable. We have a set of predictor variables that vary over time, represented by the vector $X(i, t)$. Our basic model for $\mathrm{y}$ is:

$y_{i t}=\mu_{t}+B x_{i t}+\alpha_{i}+\varepsilon_{i t}$

Where $\mu$ is an intercept that may be different for each point in time and $B$ is a vector of coefficients. The two error terms, ai and cit, behave somewhat differently. There is a different eit for each individual at each point in time, but ai only varies across individuals, not over time. We regard ai as representing the combined effect on $\mathrm{y}$ of all unobserved variables that are constant over time. On the other hand, eit represents purely random variation at each point in time.
The estimated coefficient of binary choice model cannot be interpreted as the marginal effect on the dependent variable, can only be judged from sign. If positive, it indicates that the greater the explanatory variables, the bigger the probability of the dependent variable to take one; if negative, it indicates that the smaller of the corresponding probability.

Secondly, financial sector development is a key determinant of the extent of growth and stability benefits associated with financial globalization. It not only enhances the growth benefits but also reduces vulnerability to crises, through both direct and indirect channels. [18] emphasizes that inadequate or mismanaged domestic financial sector liberalizations have been a major contributor to crises that may be associated with financial integration, [19]. That's why we add an interaction term that combines financial development and financial globalization effects to the first model. The corresponding regression equation will be given by,

$\mathrm{y}_{\mathrm{i}, \mathrm{t}}=\mu_{\mathrm{t}}+\mathrm{a}_{1} \cdot \mathrm{FD}_{\mathrm{i}, \mathrm{t}}+\mathrm{a}_{2} \cdot \mathrm{FG}_{\mathrm{i}, \mathrm{t}}+\mathrm{a}_{3} \cdot \mathrm{FD}_{\mathrm{i}, \mathrm{t}} \cdot \mathrm{FG}_{\mathrm{i}, \mathrm{t}}+$

$B x_{i t}+a_{i}+\varepsilon_{i t}$

We are interested to the interaction term coefficient (a3) between financial development indicator (FD) and financial globalisation indicator (FG).

Moreover, our hypothesis when a2 and a3 have opposite signs, a threshold effect arises.

$$
\begin{aligned}
& \frac{\partial \mathrm{y}_{\mathrm{i}, \mathrm{t}}}{\partial \mathrm{FG}_{\mathrm{i}, \mathrm{t}}}=\mathrm{a}_{2}+\mathrm{a}_{3} \text { Credit }_{\mathrm{i}, \mathrm{t}}>0 \leftrightarrow \text { Credit }_{\mathrm{i}, \mathrm{t}}>\widehat{\text { Credit }}:= \\
& -\frac{\mathrm{a}_{2}}{\mathrm{a}_{4}}
\end{aligned}
$$

\section{Results and Discussions}

Tables 1, 2 and 3 contain the main results of our econometric investigation. Table 1 reports the estimations for the first definition of crisis/noncrisis. The different combinations of the proxies generated 5 estimated equations. The GDP growth rate and the composite county risk proxies are statistically significant in all 5 equations, and that the size of the coefficients of these two variables does not vary much across equations. Although the proxies of financial development such as credit ratio, M3/GDP and credit/deposit are statistically significant, indicating partial support for the standard proposition that a higher credit increase the probability of a financial crisis. Neither the two others financial development indicators were insignificant.

The results of developing countries sample (Panel A, Table2) show the same results as those of the total sample. Thus, credit and the risk of countries have a significant impact on the increase of the chance that a country runs a 
crisis. However, an increase growth rate reduces the risk of crisis occurrence.

Then, we subdivide the group of developing countries to the most financially integrated (Panel B) and the less financially integrated countries (Panel C). Indeed, we notice in Panel B that the exchange rate played an important role

Table1: Financial development, capital flows and crises: Estimation of the occurrence of a financial crisis in the total sample

\begin{tabular}{|c|c|c|c|c|c|}
\hline \multirow{2}{*}{$\begin{array}{l}\text { Depedent Variable } \\
\text { Y(i, t) }\end{array}$} & \multicolumn{5}{|c|}{ Fixed effects logit panel } \\
\hline & (1) & (2) & (3) & (4) & (5) \\
\hline \multirow[t]{2}{*}{ Inflation } & -0.0139 & -0.00835 & $0.107^{*}$ & -0.0103 & -0.0172 \\
\hline & $(-1.059)$ & $(-0.632)$ & (1.688) & $(-0.814)$ & $(-1.453)$ \\
\hline \multirow[t]{2}{*}{ Government spending } & 3.931 & 2.470 & -6.122 & 3.349 & 2.141 \\
\hline & $(1.172)$ & $(0.727)$ & $(-0.974)$ & $(0.987)$ & $(0.628)$ \\
\hline \multirow[t]{2}{*}{ Exchange rate } & $-2.77 e-05$ & $-6.37 e-05$ & 0.000920 & $-9.44 \mathrm{e}-05$ & $-6.43 e-05$ \\
\hline & $(-0.359)$ & $(-0.802)$ & $(1.351)$ & $(-1.127)$ & $(-0.809)$ \\
\hline \multirow[t]{2}{*}{ GDP growth rate } & $-12.33^{* * *}$ & $-13.59 * * *$ & $-14.73 * * *$ & $-14.24^{* * *}$ & $-13.97 * * *$ \\
\hline & $(-4.567)$ & $(-5.079)$ & $(-4.120)$ & $(-5.390)$ & $(-5.282)$ \\
\hline \multirow[t]{2}{*}{ Term of trade } & 0.154 & 0.209 & 0.223 & 0.230 & 0.222 \\
\hline & $(0.431)$ & $(0.597)$ & $(0.396)$ & $(0.655)$ & $(0.637)$ \\
\hline \multirow[t]{2}{*}{ Country Risk } & $1.185^{* * *}$ & $1.217 * * *$ & $1.092^{*}$ & $0.790 * *$ & $0.859 * *$ \\
\hline & $(3.418)$ & $(3.385)$ & (1.818) & $(2.315)$ & $(2.558)$ \\
\hline \multirow[t]{2}{*}{ Capital flows } & 0.0776 & 0.0268 & 0.520 & 0.0305 & 0.0387 \\
\hline & $(0.330)$ & $(0.160)$ & $(0.793)$ & $(0.179)$ & $(0.190)$ \\
\hline Credit & $\begin{array}{l}3.447 * * * \\
(4.852)\end{array}$ & & & & \\
\hline \multicolumn{2}{|l|}{ M3/PIB } & $\begin{array}{l}3.697 * * * \\
(3.667)\end{array}$ & & & \\
\hline \multicolumn{2}{|l|}{ Capitalisation } & & $\begin{array}{l}-0.527 \\
(-0.913)\end{array}$ & & \\
\hline \multicolumn{2}{|c|}{$\begin{array}{l}\text { Total aseets of financil } \\
\text { system }\end{array}$} & & & 0.445 & \\
\hline Credit/Deposit & & & & $(0.554)$ & $\begin{array}{l}0.860^{* * *} \\
(2.820)\end{array}$ \\
\hline Observations & 981 & 981 & 536 & 981 & 981 \\
\hline Number of countries & 41 & 41 & 26 & 41 & 41 \\
\hline Wald test & 0.00 & 0.00 & 0.00 & 0.00 & 0.00 \\
\hline
\end{tabular}

(significant) in crisis probability. Conversely, the estimation relative to the group of the less financially integrated countries (Panel C) shows that financial development indicator (Credit) losses significance. This separation of samples leads us to deduct that the degree of the financial integration plays an important role in the determination of the crisis occurrence factors.

Table 2: Estimation of occurrence crisis: separation of developing countries groups

\begin{tabular}{llll}
\hline Dependant Variable : & \multicolumn{2}{l}{ Fixed effect logit panel } & Panel B \\
\cline { 2 - 4 } Yanel A & Panel C \\
\hline Credit & $2.56^{* * *}$ & $3.27^{* * *}$ & 1.79 \\
& $(3.28)$ & $(2.89)$ & $(1.47)$ \\
Capital flows & 0.023 & 1.16 & -0.012 \\
& $(0.14)$ & $(1.37)$ & $(-0.097)$ \\
Inflation & -0.012 & 0.10 & -0.021 \\
& $(-0.96)$ & $(1.61)$ & $(-1.42)$ \\
Gouvernement spending & 3.18 & -2.93 & 3.59 \\
& $(0.93)$ & $(-0.34)$ & $(0.86)$ \\
Exchange Rate & $-4.89 \mathrm{e}-05$ & $0.0013^{*}$ & $-6.91 \mathrm{e}-05$ \\
& $(-0.61)$ & $(1.71)$ & $(-0.74)$ \\
GDP Growth Rate & $-12.43^{* * *}$ & $-12.92^{* * *}$ & $-11.63^{* * *}$ \\
& $(-4.59)$ & $(-3.17)$ & $(-3.08)$ \\
\hline
\end{tabular}




\begin{tabular}{llll}
\hline Terms of Trade & 0.21 & 0.058 & -0.125 \\
& $(0.60)$ & $(0.087)$ & $(-0.26)$ \\
Country Risk & $1.0^{* * *}$ & $1.25^{*}$ & $1.15^{* * *}$ \\
& $(2.89)$ & $(1.73)$ & $(2.585)$ \\
Observations & 837 & 311 & 526 \\
Number of countries & 35 & 13 & 22 \\
Wald test & 0.00 & 0.00 & 0.00 \\
\hline
\end{tabular}

Panel A: Developing Countries Sample.Panel B: Sample of the Most Financially Integrated Countries.Panel C: Sample of the Lees Financially Integrated Countries.

In table 3, addition of interaction term between capital flows and financial development has a significant negative impact which validates hypothesis that capital flows can change sign towards its effect on crisis probability. Capital flows appear reducing the chance of crisis occurrence at a determined financial development threshold which is reached by studied developing countries (Panel B and C). This means that there is a threshold from which the coefficient of capital movements changes sign. This latter is determined from the marginal impact of capital flows as mentioned in equation (3). This justifies that from a certain financial development level, the capital flows has just brought its initial enthusiasm while reducing the macroeconomic volatility. So, this threshold deducts in the following way:

For the Panel B: developing countries:

total effect of capital flows $=0.551-2.712 *$ credit
This effect will equal to zero at the beginning of the credit* $=20 \%$ of GDP. From this threshold, capital flows become an explanatory factor of increasing probability of crisis in a developing country. A financial system which is in phase of maturity can run instabilities which can engender an escalation of the volatility along with the financial opening.

For the Panel C: developing countries which are the most financially integrated total effect of capital flows

$$
=3.409-5.756 * \text { credit }
$$

This effect will equal to zero at the beginning of the credit* $=60 \%$ of GDP. From this threshold, capital flows become an explanatory factor of increasing probability of crisis in a developing country.

Table 3: Estimation of occurrence of crises: The threshold Effect of financial development

\begin{tabular}{|c|c|c|c|c|}
\hline \multirow{2}{*}{$\begin{array}{l}\text { Depedent Variable : } \\
\text { Y (i, t) }\end{array}$} & \multicolumn{4}{|c|}{ Fixed Effect Logit Panel } \\
\hline & Panel A & Panel B & Panel C & Panel D \\
\hline \multirow[t]{2}{*}{ Credit } & $3.656^{* * *}$ & 0.908 & -0.313 & 0.567 \\
\hline & $(4.332)$ & $(0.812)$ & $(-0.193)$ & $(0.323)$ \\
\hline \multirow[t]{2}{*}{ Capital Flows } & -0.000868 & 0.551 & $3.409^{* * *}$ & 0.260 \\
\hline & $(-0.00343)$ & (1.085) & $(2.901)$ & $(0.832)$ \\
\hline \multirow[t]{2}{*}{ Credit *Capital Flows } & 0.404 & $-2.712^{*}$ & $-5.756^{* * *}$ & -1.948 \\
\hline & $(0.458)$ & $(-1.959)$ & $(-2.604)$ & $(-1.003)$ \\
\hline \multirow[t]{2}{*}{ Inflation } & -0.0137 & -0.0133 & $0.106^{*}$ & -0.0228 \\
\hline & $(-1.046)$ & $(-1.058)$ & (1.670) & $(-1.466)$ \\
\hline \multirow[t]{2}{*}{ Government Spending } & 3.847 & 3.767 & 2.621 & 4.015 \\
\hline & $(1.145)$ & $(1.094)$ & $(0.296)$ & $(0.947)$ \\
\hline \multirow[t]{2}{*}{ Exchange Rate } & $-3.06 \mathrm{e}-05$ & $-3.38 \mathrm{e}-05$ & 0.000951 & $-5.81 \mathrm{e}-05$ \\
\hline & $(-0.394)$ & $(-0.425)$ & $(1.173)$ & $(-0.630)$ \\
\hline \multirow[t]{2}{*}{ GDP Growth Rate } & $-12.27 * * *$ & $-12.91 * * *$ & $-14.11^{* * *}$ & $-12.05^{* * *}$ \\
\hline & $(-4.537)$ & $(-4.771)$ & $(-3.437)$ & $(-3.161)$ \\
\hline \multirow[t]{2}{*}{ Terms of trade } & 0.161 & 0.198 & 0.0623 & -0.150 \\
\hline & $(0.453)$ & $(0.553)$ & $(0.0910)$ & $(-0.318)$ \\
\hline \multirow[t]{2}{*}{ Country Risk } & $1.192^{* * *}$ & $0.951^{* * *}$ & 1.183 & $1.057^{* *}$ \\
\hline & (3.446) & $(2.659)$ & (1.627) & (2.328) \\
\hline Observations & 981 & 837 & 311 & 526 \\
\hline Number of countries & 41 & 35 & 13 & 22 \\
\hline Wald Test & 0.00 & 0.00 & 0.00 & 0.00 \\
\hline
\end{tabular}

Panel A: Total Sample.Panel B: Developing Countries Sample.Panel C: Sample of the Most Financially Integrated Countries.Panel D: Sample of the Lees Financially Integrated Countries.

Our results support some empirical studies which showed that the banking crises were generally preceded by financial liberalization. [20] have realized an important empirical study, concerning 20 countries in Asia, Latin America, Europe and
Middle East, during the years 1970-1995. Their main results confirmed by later works, are the following ones: on one hand, the banking crises were rare and had no links with the crises of balances of during 1970 s, period when financial 


\section{Available online at www.managementjournal.info}

markets were still strictly controlled. On the other hand, following

the general movement of financial liberalization in the world, the number of banking crises strongly increased, and most of the banking crises are preceded by policies of financial liberalization. Moreover, Demirgurc-Kunt and Detragiache (1998) showed that the financial liberalization increases the probability of banking crisis. This was made by a study concerning 53 countries during the years 1980-1995.

The main result of this study is the dominating role of credit ratio such us one of alerts in the occurrence of crisis. Indeed, it seems that a reduction in the growth rate is associated with a high probability of crisis. The foreign capital flows contributed to increase the difficulties in the most integrated countries. These results confirm those obtained in previous works. Besides, it appears in our study that interaction of financial domestic sector with financial integration brings of such significance to explain the crisis. This is understandable by the fact that banks would so feel more to perform their function of intermediation once a level of financial integration is realized or reaches.

\section{Conclusion}

The contribution of this paper aims to show the relation between capital flows and occurrence of crises conditional to the development level of domestic financial systems. The interaction between domestic financial development and capital flows is a determinant which does not miss importance of the scale of the volatility brought by financial openness. However, capital flows is associated with the highest probability of crisis if level of domestic financial development is at determined threshold. Our empirical results

\section{References}

1. Kaminsky G, Reinhart C (1999) The twin crisis: The causes of banking and balance-of-payment problems. American Economic Review, 89:473-500.

2. Maurice Obstfeld (1986) Rational and SelfFulfilling Balance-of-Payments Crises, NBER Working Papers 1486, National Bureau of Economic Research, Inc.

3. Mckinnon, R.I. and H. Pill (1997) Credible Economic Liberalizations and Overborrowing. The American Economic Review, 87(2), pp. 189-203.

4. Calvo Guillermo A, Leonardo Leiderman, Carmen M Reinhart (1996) Inflows of capital to developing countries in the 1990s. J. Economic Perspectives, 10(2):123-39. suggested that the level of financial development threshold, measured by the ratio of private credit to GDP, is estimated to be $20 \%$ and $60 \%$ respectively to developing countries and the most integrated ones. Departing from this level, we expect risks of financial openness. It seems, however, that countries, which are at an intermediate phase of financial sector development, can be the most unstable.

Generally, countries can benefit from financial globalization. Financial liberalization develops the financial system, enhances the financing opportunities and increases investment and liquidity. However, sound macroeconomic and financial fundamentals are keys in reducing the probability of crises and to be able to manage risks more effectively.

Preventing financial crises should be one of the important objectives of policymakers because of the high economic losses caused by crises. The initial conditions matter; the effectiveness of policies relies on the degree of integration with world markets. Countries with a very low degree of integration and with underdeveloped financial systems are more able to run instability the caused by financial globalization than the less integrated countries. Countries with a low level of integration should prepare its financial sectors to cope with capital markets liberalization. Then, large capital flows can create severe problems if the domestic financial sector doesn't manage risk properly and doesn't have the right incentives. However, it is not an obligation that all the conditions must be met before governments liberalize their financial sectors. In terms of policy conclusion, it suggests that the financial domestic system has to be a prerequisite for financial integration decision.

5. Kindleberger, C.P., Manias, Panics and Crashes (1996). A History of Financial Crises, Mac Millan, 3e éd..

6. Bordo Michael, Barry Eichengreen, Douglas Irwin (1999) Is Globalization Today Really Different from Globalization a Hundred Years Ago? Brookings Trade Policy Forum, pp.1-73.

7. Bordo M, Eichengree B, Klingebiel D, MartinezPeria MS (2001) Financial Crises: Lessons from the last 120 years. Economic Policy.

8. Frankel J, Rose A (1996) Currency crashes in emerging markets: An empirical treatment. J, Int. Economics, 41:3-4:351-66. 


\section{Available online at www.managementjournal.info}

9. Demirgüc-Kunt A, Detragiache E (1998) Financial liberalization and financial fragility, International Monetary Fund, Working Paper 83.

10. Caprio G, Klingebiel D (1997) Bank Insolvency: Bad Luck, Bad Policy, Bad Banking? Annual Bank Conference on Development Economics , World Bank Economic Review.

11. Burnside C, Eichenbaum M, Rebelo S (2001) Prospective Deficits and the Asian Currency Crises Forthcoming in the J. Political Economy.

12. Cole Rebel A, Gunther Jeffery W (1995) Separating the likelihood and timing of bank failure, J. Banking \& Finance, Elsevier, 19(6):10731089.

13. Gonzalez-Hermosillo B, Pazarbasioglu C, Billings R (1997) Determinants of Banking System Fragility: A Case Study of Mexico. IMF Staff Papers, 44(3):295-315.

14. Luc Laeven, Fabian Valencia (2010) Resolution of Banking Crises: The Good, the Bad, and the Ugly, IMF Working Papers 10/146, International Monetary Fund.
15. Thorsten Beck and Asli Demirgüç-Kunt (2009) Financial Institutions and Markets Across Countries and over Time: Data and Analysis, World Bank Policy Research Working Paper No. 4943.

16. Lane Philip R, Gian Maria Milesi-Ferretti (2007) The External Wealth of Nations Mark II, J. Int. Economics, 73:223-250.

17. Greene WH (1997) Econometric Analysis, 3rd ed. Prentice-Hall, Upper Saddle River, NJ.

18. Frederic S Mishkin (2007) Is Financial Globalization Beneficial? J. Money, Credit and Banking, 39(2-3):259-94,03.

19. Kose MA, Prasad E, Rogoff K, Wei SJ (2006) Financial Globalization: A Reappraisal IMF Working Paper, WP/06/189.

20. Kaminsky, Graciela L. and Reinhart, Carmen M. (1996) The Twin Crises: The Causes of Banking and Balance-of-Payments Problems." International Finance Discussion Paper No. 544, Board of Governors of the Federal Reserve System. 